\title{
Pengaruh Tanggung Jawab Sosial Perusahaan terhadap Kinerja Keuangan dengan Tata Kelola Perusahaan sebagai Pemoderasi
}

\author{
Dhesy Eka Putri Shafariani
}

Program Pasca Sarjana Universitas Brawijaya Malang Jl. MT. Haryono 165, Malang.

\begin{abstract}
The aim of this study is to analyze the effect of corporate social responsibility (CSR) to financial performance with good governance as a moderating variable. Data was drawn from public companies which participate in the Corporate Governance Perception Index (CGPI) held by The Indonesian Institute for Corporate Governance (IICG) for year of 2009-2011. MRA (Moderated Regression Analysis) was used to analyze the data. The results show that empirically, financial performance was influenced by $C S R$, and good governance is moderating variable in relationship of CSR and financial performance.
\end{abstract}

Keywords: corporate social responsibility, financial performance, good governance.

\section{PENDAHULUAN}

Terdapat pandangan yang menyatakan bahwa perusahaan tidak hanya dinilai dari kinerja keuangannya saja, tetapi juga dinilai dari kinerja sosial perusahaan (corporate social performance), yaitu bagaimana perusahaan tidak hanya memuaskan para pemilik modal, tetapi juga harus memuaskan seluruh stakeholdernya. Pengambilan keputusan ekonomi hanya dengan melihat kinerja keuangan suatu perusahaan, saat ini sudah tidak relevan lagi. Eipsten dan Freedman (1994) menemukan bahwa investor lebih tertarik terhadap informasi sosial yang dilaporkan dalam laporan tahunan. Untuk itu dibutuhkan suatu sarana yang dapat memberikan informasi mengenai aspek sosial, lingkungan dan keuangan secara sekaligus.

Pandangan ini merupakan salah satu faktor yang menyebabkan bahwa perusahaan harus melaksanakan aktivitas sosial, di samping aktivitas operasionalnya. Pengambilan keputusan ekonomi saat ini, tidak hanya melihat kinerja keuangannya saja karena simpulan baik buruknya kinerja keuangan perusahaan tidak cukup hanya dilihat dari besarnya laba yang dihasilkan. Permasalahannya saat ini kondisi kinerja keuangan perusahaan saja tidak cukup menjamin perusahaan tumbuh secara berkelanjutan (sustainable). Keberlanjutan perusahaan hanya akan terjamin apabila perusahaan memperhatikan dimensi sosial dan lingkungan hidup (Brammer et al., 2005; Paul dan Siegel, 2006).

Owen (2005) mengatakan bahwa kasus Enron di Amerika telah menyebabkan perusahaan-perusahaan lebih memberikan perhatian yang besar terhadap pelaporan tanggung jawab sosial perusahaan. Isu-isu yang berkaitan dengan reputasi, manajemen risiko dan keunggulan kompetitif nampak menjadi kekuatan yang mendorong perusahaan untuk melakukan pengungkapan informasi sosial. Finch (2005) menunjukkan bahwa motivasi perusahaan untuk melakukan pengungkapan sosial lebih banyak dipengaruhi oleh usaha untuk mengkomunikasikan kepada stakeholder mengenai kinerja manajemen dalam mencapai manfaat bagi

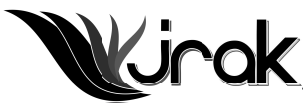

Jurnal Reviu Akuntans dan Keuangan ISSN: 2088-0685 Vol.3 No. 2, Oktober 2013 Pp 493-506 perusahaan dalam jangka panjang. 
Pengaruh

Tanggung

Jawab...
Ruang lingkup informasi kinerja keuangan yang diungkapkan dalam laporan keuangan perusahaan semakin diperluas, tidak hanya memberikan informasi keuangan konvensional yang terbatas pada angka-angka akuntansi, tetapi laporan keuangan harus mengakomodasi kepentingan para pengambil keputusan dengan cara menampilkan pertanggungjawaban sosialnya, yang nantinya mampu menampilkan kinerja perusahaan secara lengkap. Global Compact Initiative (2002) menyebut pemahaman ini dengan $3 P$ (profit, people, planet), yaitu bahwa tujuan bisnis adalah mencari laba (profit), tetapi seharusnya juga menyejahterakan orang (people) dan menjamin keberlanjutan hidup planet ini. Salah satu bentuk tanggung jawab kepada stakeholders dapat diwujudkan dengan melakukan tanggung jawab sosial perusahaan (corporate social responsibility).

Tanggung jawab sosial perusahaan merupakan bentuk pertanggungjawaban perusahaan terhadap masyarakat dan lingkungan yang semakin luas, yang mencakup aspek ekonomi, lingkungan, dan sosial budaya. Penerapan tanggung jawab sosial perusahaan dipercaya dapat meningkatkan kinerja keuangan perusahaan karena para investor cenderung menanamkan modal kepada perusahaan yang melakukan kegiatan tanggung jawab sosial perusahaan. Oleh karena itu, perusahaan-perusahaan dapat menggunakan informasi tanggung jawab sosial perusahaan sebagai salah satu keunggulan kompetitif perusahaan. Perusahaan yang telah menerapkan tanggung jawab sosial perusahaan akan melakukan pelaporan dan pengungkapan tanggung jawab sosial perusahaan, selain laporan keuangan. Hal ini dilakukan karena perusahaan menginginkan legitimasi dan nilai positif dari masyarakat sehingga perusahaan akan memperoleh laba dalam jangka waktu yang panjang.

Bagi perusahaaan, bentuk tanggung jawab dalam penerapan tanggung jawab sosial perusahaan membutuhkan biaya yang relatif besar agar bisa berjalan dengan baik dan berkesinambungan. Hal ini merupakan salah satu permasalahan yang akan memengaruhi kinerja keuangan perusahaan. Di satu sisi perusahaan ingin memperoleh laba sebesar-besarnya dengan biaya yang sekecil mungkin, tetapi dengan adanya tekanan untuk melakukan tanggung jawab sosial perusahaan, tentu saja hal ini akan mengurangi laba yang diharapkan oleh perusahaan karena harus mengeluarkan biaya untuk tanggung jawab sosial perusahaan tersebut.

Peristiwa yang terjadi belakangan ini juga ikut menyadarkan akan arti penting penerapan tanggung jawab sosial perusahaan. Sebagai contoh adalah masalah isu pencemaran lingkungan yang dilakukan perusahan tambang PT. Newmont Minahasa Raya yang beroperasi di wilayah Teluk Buyat, Kabupaten Bolaang Mongondouw Sulawesi Utara tahun 2004. Limbah tailing (sisa buangan tambang) yang dihasilkan perusahaan tambang emas itu mengakibatkan lebih dari 100 warga di Teluk Buyat terkena penyakit Minamata. Penyakit Minamata yang selama ini menyerang syaraf dikenal sebagai penyakit yang muncul akibat terkontaminasi logam berat seperti arsenik dan merkuri. Sejumlah LSM seperti Walhi dan Jatam menyampaikan bahwa penyakit yang diderita masyarakat di sekitar Teluk Buyat karena bertambahnya kadar arsen dan merkuri di laut di tempat PT Newmont membuang limbahnya (www.bisnis.com).

Sejalan dengan perkembangan tersebut, pemerintah Indonesia telah menetapkan berbagai regulasi terkait lingkungan diantaranya, UU No.23 tahun 1997 tentang pengelolaan lingkungan hidup dan berbagai peraturan pelaksanaannya. Pasal 6 ayat 2 UU No.23 tahun 1997 ini yang berbunyi "Setiap orang yang melakukan usaha dan/atau kegiatan wajib memberikan informasi yang benar dan akurat tentang pengelolaan lingkungan hidup". Keputusan Ketua BAPEPAM dan Lembaga Keuangan melalui No.Kep-134/BL/2006 yang mulai berlaku sejak tanggal 7 Desember 2006 juga mewajibkan laporan keuangan tahunan perusahaan sekurang-kurangnya memuat uraian tentang aktivitas dan biaya yang dikeluarkan terkait tanggung jawab sosial perusahaan terhadap masyarakat dan lingkungan.

Penelitian Mahoney dan Robert (2003), Tsoutsura (2004), dan Suratno et al. (2007) membuktikan bahwa kinerja keuangan dipengaruhi oleh pengungkapan informasi tentang tanggung jawab sosial perusahaan atau yang sering disebut 
dengan corporate social responsibility. Penelitian yang menginvestigasi hubungan corporate social responsibility dan kinerja perusahaan yang meliputi kinerja keuangan dan kinerja ekonomi dilakukan oleh Mahoney, et al. (2003) yang meneliti hubungan antara kinerja sosial dan lingkungan perusahaan dengan kinerja keuangan ( $R O E$ dan $R O A$ ) hasilnya menunjukkan hubungan positif. Penelitian Suratno, et al. (2007) menunjukkan bahwa environmental performance berpengaruh positif terhadap economic performance. Fauzi, et al. (2007) meneliti hubungan corporate social performance dan corporate financial performance (ROE dan $R O A$ ). Hasil studi tidak menunjukkan adanya hubungan antara corporate social performance dan corporate financial performance ( $R O E$ dan $R O A)$. Fiori, et al. (2007) meneliti corporate social responsibility terhadap kinerja perusahaan menggunakan proksi stock price. Hasil empirisnya menunjukkan corporate social responsibility tidak memengaruhi stock price.

Hubungan kinerja keuangan dengan tanggung jawab sosial perusahaan dapat diketahui dari citra yang terbentuk pada perusahaan tersebut. Tanggung jawab sosial perusahaan yang baik mewakili pola kinerja keuangan perusahaan yang baik pula. Selain itu, tanggung jawab sosial perusahaan juga menunjukan bahwa secara finansial perusahaan tersebut dapat mengatur dan mengelola perusahaannya dengan baik. Wujud pengelolaan tersebut dapat dilihat oleh masyarakat melalui laporan tanggung jawab sosial perusahaan yang diungkapkan perusahaan, baik yang berhubungan dengan lingkungan intern perusahaan maupun yang berhubungan dengan lingkungan ekstern perusahaan. Semakin banyak item yang diungkapkan, maka perusahaan juga semakin transparan dalam melakukan pengelolaan.

Berdasarkan latar belakang masalah di atas, maka perumusan masalah dalam penelitian ini adalah sebagai berikut:

1. Apakah tanggung jawab sosial perusahaan berpengaruh terhadap kinerja keuangan?

2. Apakah tanggung jawab sosial perusahaan berpengaruh terhadap kinerja keuangan dengan tata kelola perusahaan sebagai pemoderasi?

\section{METODE}

Penelitian ini menggunakan pendekatan kuantitatif karena menekankan pada pengujian teori-teori melalui pengukuran variabel-variabel penelitian dengan angka dan melakukan analisis data dengan prosedur statistik. Di samping itu, penelitian ini dilakukan dengan maksud explanatory, yaitu penelitian yang menggunakan hubungan kausal antara variabel-variabel penelitian melalui pengujian hipotesis. Populasi yang digunakan dalam penelitian ini adalah laporan tahunan perusahaan-perusahaan yang terdaftar di Bursa Efek Indonesia periode tahun 2009-2011 yang memublikasikan laporan tanggung jawab sosial tahun 2009-2011 dan berpartisipasi dalam Corporate Governance Perception Index (CGPI) yang diselenggarakan oleh The Indonesian Institute for Corporate Governance (IICG).

Sampel adalah bagian dari jumlah dan karakteristik yang dimiliki oleh populasi. Untuk itu sampel yang diambil harus benar-benar dapat mewakili suatu populasi (Sugiyono, 2004:73). Teknik pengambilan sampel yang digunakan dalam penelitian ini adalah dengan menggunakan purposive sampling, yaitu dilakukan dengan mengambil sampel dari populasi berdasarkan suatu kriteria tertentu. Kriteria yang digunakan dapat berdasarkan pertimbangan (judgment) tertentu atau jatah (quota) tertentu. Dalam penelitian ini purposive sampling dengan menggunakan judgment sampling, judgment sampling adalah metode sampling yang digunakan atas dasar beberapa pertimbangan kriteria (Hartono, 2010:79). 
Pengaruh

Tanggung

Jawab...

496

Table 1

Statistik Deskriptif
Teknik analisis data yang digunakan yaitu 1) statistik deskriptif digunakan untuk memberikan gambaran maupun deskripsi mengenai nilai rata-rata, standar deviasi, nilai maksimum, dan nilai minimum dari data penelitian (Ghozali, 2006:19). 2) Statistik Inferensial sering juga disebut statistik induktif atau statistik probabilitas merupakan teknik statistik yang digunakan untuk menganalisis data sampel dan hasilnya diberlakukan untuk populasi (Ghozali, 2006:145). Untuk menguji pengaruh variabel pengungkapan tanggung jawab sosial terhadap variabel kinerja keuangan (return saham) dan untuk menguji pengaruh interaksi dari variabel moderasi tata kelola perusahaan digunakan Moderated Regresi Analysis (MRA), yaitu aplikasi khusus regresi berganda linier yang dalam persamaannya mengandung unsur interaksi (perkalian dua atau lebih variabel independen).

\section{HASIL DAN PEMBAHASAN}

Analisis analistik statistik deskriptif bertujuan untuk memberikan gambaran atau deskripsi suatu data (Ghozali, 2006:19). Penelitian ini menggunakan 3 variabel, yang terdiri dari variabel dependen, yaitu kinerja keuangan, variabel independen berupa pengungkapan tanggung jawab sosial, serta variabel pemoderasi, yaitu tata kelola perusahaan. Pengukuran statistik deskriptif dalam penelitian ini berupa nilai minimum dan maksimum, nilai rata-rata, serta standar deviasi. Tabel 1 menyajikan statistik deskriptif untuk ketiga variabel yang diteliti.

\begin{tabular}{lccccc}
\hline \multicolumn{1}{c}{ Variabel } & N & Minimum & Maksimum & Rata-Rata & Std.Deviasi \\
\hline $\begin{array}{l}\text { Tanggung Jawab } \\
\text { Sosial Perusahaan }\end{array}$ & 89 & 0.004 & 0,991 & 0,298 & 0,260 \\
$\begin{array}{l}\text { Tata Kelola } \\
\text { Perusahaan }\end{array}$ & 89 & 0,004 & 0,920 & 0,325 & 0,238 \\
$\begin{array}{l}\text { Kinerja Keuangan } \\
\text { Valid N (listwise) }\end{array}$ & 89 & 0,001 & 0,980 & 0,291 & 0,282 \\
\hline
\end{tabular}

Pada Tabel 1 di atas dijelaskan bahwa variabel pengungkapan tanggung jawab sosial yang diproksikan dengan corporate social responsibility index (CSRI) memiliki nilai minimum sebesar 0,004 dan nilai maksimum 0,991, sedangkan nilai rata-rata secara keseluruhan sebesar 0,298 dengan standar deviasi sebesar 0,260 yang menunjukkan tingkat variasi sebaran data, dimana angka standar deviasi semakin kecil atau mendekati 0 menunjukkan variasi data semakin kecil. Pengungkapan secara umum hanya berada pada kisaran $29 \%$, gambaran ini menerangkan bahwa indeks pengungkapan tanggung jawab sosial yang dilakukan oleh perusahaan yang mengikuti CGPI masih tergolong rendah.

Variabel tata kelola perusahaan yang diproksikan dengan corporate governance perception index (CGPI) memiliki nilai minimum sebesar 0,004 dan nilai maksimum 0,920, sedangkan nilai rata-rata secara keseluruhan sebesar 0,325 dengan standar deviasi yang menunjukkan tingkat sebaran data yaitu sebesar 0,238. Hasil analisis menunjukkan bahwa indeks penerapan tata kelola perusahaan yang dilakukan oleh perusahaan yang mengikuti CGPI sebesar $32 \%$

Variabel kinerja keuangan yang diproksikan dengan return saham memiliki nilai minimum sebesar 0,001 dan nilai maksimum 0,980, sedangkan nilai ratarata secara keseluruhan sebesar 0,291 dengan standar deviasi yang menunjukkan variasi data yaitu diperoleh hasil sebesar 0,282. Hasil analisis menunjukkan kemampuan perusahaan untuk menghasilkan kentungan/laba sebesar $28 \%$. 
Selajutnya pengujiaan hipotesis dalam penelitian ini, yaitu meliputi koefisien determinasi $\left(\mathrm{R}^{2}\right)$, uji $\mathrm{F}$ (simultan), dan uji t (parsial). Hasil pengujian hipotesis secara lengkap dapat diuraikan sebagai berikut:

\section{Koefisien Determinasi $\left(R^{2}\right)$}

Pengujian koefisien determinasi $\left(\mathrm{R}^{2}\right)$ bertujuan untuk mengukur seberapa jauh kemampuan model menjelaskan variasi variabel dependen. Tabel 2 berikut ini menunjukkan nilai koefisien determinasi $\left(\mathrm{R}^{2}\right)$.

\begin{tabular}{cc}
\hline Model & Adjusted R Square \\
\hline 1 & 0,398 \\
\hline
\end{tabular}

Hasil analisis menunjukkan bahwa nilai Adjusted $R$ Square sebesar 0,398 atau $39,8 \%$. Hal ini menunjukkan bahwa kinerja keuangan dapat dijelaskan oleh variabel tanggung jawab sosial perusahaan dengan tata kelola perusahaan sebagai variabel pemoderasi, sebesar $39,8 \%$, sedangkan sisanya, yaitu sebesar $60,2 \%$ dijelaskan oleh variabel lain di luar model.

\section{Hasil Uji F (Simultan)}

Untuk mengetahui variabel independen secara simultan (bersama-sama) mempunyai pengaruh terhadap variabel dependen atau tidak berpengaruh, digunakan uji $\mathrm{F}$ (F-test), yaitu dengan membandingkan $\mathrm{F}_{\text {hitung }}$ dan $\mathrm{F}_{\text {tabel }}$ pada taraf nyata $5 \%(\alpha=0,05)$ atau perbandingan nilai signifikan F. Apabila $F_{\text {hitung }}>F_{\text {tabel }}$ atau nilai Sig. $\mathrm{F}<0,05$, berarti $\mathrm{H}_{\mathrm{o}}$ ditolak, sebaliknya $\mathrm{F}_{\text {hitung }}<\mathrm{F}_{\text {tabel }}$ atau nilai Sig. $\mathrm{F}>0,05$, berarti $\mathrm{H}_{\mathrm{o}}$ diterima. Hasil uji $\mathrm{F}$ disajikan pada Tabel 3 berikut.

\begin{tabular}{ccl}
\hline F & Sig. & Keterangan \\
\hline 20,434 & 0,000 & $\mathrm{H}_{\mathrm{a}}$ diterima \\
\hline
\end{tabular}

Sumber: Data Diolah

Dari hasil analisis regresi berganda dengan menggunakan $\mathrm{Df}_{1}=3$ dan $\mathrm{Df}_{2}=$ 85 pada alpha sebesar $5 \%$ diperoleh nilai $\mathrm{F}_{\text {hitung }}$ sebesar 20,434 dengan tingkat signifikansi sebesar 0,000 . Hasil perhitungan dapat dikatakan bahwa variabel tanggungjwab sosial perusahaan, tata kelola perusahaan dan moderasi secara bersama-sama berpengaruh terhadap kinerja keuangan.

\section{Hasil Uji $t$}

Tabel 4 berikut ini menunjukkan hasil uji t dengan menggunakan analisis regresi sederhana.

\begin{tabular}{lcc}
\hline \multirow{2}{*}{ Model } & $\begin{array}{c}\text { Unstandardized } \\
\text { Coefficients }\end{array}$ & Nilai Probabilitas \\
\cline { 2 - 3 } & $\mathbf{B}$ & 0,000 \\
\hline (Constant) & $-1,762$ & 0,000 \\
Tanggung Jawab Sosial Perusahaan & 2,066 & 0,000 \\
Tata Kelola Perusahaan & 1,546 & 0,026 \\
Moderasi & $-2,252$ & \\
\hline
\end{tabular}

Sumber: Data Diolah

Nilai constant diperoleh hasil sebesar -1,762, artinya apabila perusahaan tidak melakukan tanggung jawab sosial, kinerja keuangan perusahaan akan mengalami penurunan sebesar 1,762 persen. 
Pengaruh

Tanggung

Jawab...

498

Tabel 5

Ringkasan

Hasil Uji Hipotesis
Nilai koefisien regresi untuk variabel tanggung jawab sosial perusahaan adalah positif sebesar 2,066 sehingga dapat dikatakan bahwa pengaruh variabel tanggung jawab sosial perusahaan terhadap kinerja keuangan adalah berbanding lurus, dapat diartikan jika terdapat peningkatan 1 satuan dari variabel tanggung jawab sosial, akan meningkatkan nilai kinerja keuangan sebesar 2,066 persen. Hasil uji t didapatkan nilai signifikansi sebesar $0,000<0,05$ sehingga dapat dikatakan bahwa variabel tanggung jawab sosial perusahaan berpengaruh positif terhadap variabel kinerja keuangan.

Nilai koefisien regresi untuk variabel tata kelola perusahaan adalah positif sebesar 1,546 sehingga dapat dikatakan bahwa pengaruh variabel tata kelola perusahaan terhadap kinerja keuangan adalah berbanding lurus, dapat diartikan jika terdapat peningkatan 1 satuan dari variabel tata kelola perusahaan, akan meningkatkan nilai kinerja keuangan sebesar 1,546 persen. Hasil uji t didapatkan nilai signifikansi sebesar $0,000<0,05$ sehingga dapat dikatakan bahwa variabel tata kelola perusahaan berpengaruh positif terhadap variabel kinerja keuangan.

Nilai koefisien regresi untuk variabel moderasi adalah negatif sebesar 2,252 sehingga dapat dikatakan bahwa pengaruh variabel moderasi terhadap kinerja keuangan adalah berbanding terbalik, dapat diartikan jika terdapat peningkatan 1 satuan dari variabel moderasi, akan menurunkan nilai kinerja keuangan sebesar 2,252 persen. Hasil uji t didapatkan nilai signifikansi sebesar 0,026<0,05 sehingga dapat dikatakan bahwa variabel moderasi berpengaruh negatif terhadap variabel kinerja keuangan.

Berdasarkan hasil analisis Moderated Regresi Analysis (MRA) dengan metode uji interaksi di atas dapat dilihat bahwa variabel yang yang digunakan meliputi tanggung jawab sosial perusahaan, tata kelola perusahaan, dan moderasi berpengaruh terhadap kinerja keuangan. Hasil uji interaksi menunjukkan bahwa tata kelola perusahaan memoderasi pengaruh tanggung jawab sosial terhadap kinerja keuangan didapatkan nilai signifikansi sebesar 0,026. Nilai koefisien regresi untuk variabel moderat adalah $-2,252$, tanda negatif diartikan bahwa hubungan antara variabel moderat dengan kinerja keuangan adalah berbanding terbalik, semakin tinggi nilai dari interaksi antara tanggung jawab sosial perusahaan (corporate social responsibility) dengan tata kelola perusahaan (corporate governance) maka nilai dari variabel kinerja keuangan akan semakin rendah, begitu juga sebaliknya, sedangkan nilai -2,252 dapat diartikan jika terdapat peningkatan 1 satuan dari variabel moderat, akan menurunkan nilai kinerja keuangan sebesar 2,252 persen. Nilai signifikasi pada uji hipotesis dua $\left(\mathrm{H}_{2}\right)$ menunjukkan nilai 0,026 yang berarti $<0,05($ sig. $<\alpha)$ sehingga dapat dikatakan bahwa tata kelola perusahaan terbukti sebagai variabel moderasi yang memperlemah pengaruh tanggung jawab sosial perusahaan terhadap kinerja keuangan sehingga hipotesis dua $\left(\mathrm{H}_{2}\right)$ diterima. Ringkasan hasil uji hipotesis dapat dilihat pada Tabel 5.

\begin{tabular}{ccc}
\hline Hipotesis & Sig. & Keputusan \\
\hline $\mathrm{H}_{1}$ & 0,000 & Diterima \\
$\mathrm{H}_{2}$ & 0,026 & Diterima \\
\hline
\end{tabular}

Sumber: Data Diolah

Hasil ringkasan uji hipotesis menunjukkan bahwa hipotesis 1 dan 2 yang diajukan dalam penelitian ini terbukti diterima. Pada dasarnya pengujian hipotesis terdapat dua yaitu uji satu arah dan dua arah. Pengujian hipotesis dalam penelitian ini menggunakan satu arah, dimana pengujian satu arah digunakan sebagai dasar dalam penentuan pengaruh positif dari hasil analisis yang akan dilakukan. Hipotesis 1 menyatakan tanggung jawab sosial perusahaan berpengaruh terhadap kinerja keuangan dapat diterima dan hipotesis 2 yang menyatakan tata kelola perusahaan sebagai variabel moderasi tidak terbukti memperkuat pengaruh tanggung jawab sosial perusahaan terhadap kinerja keuangan. 
Dari hasil pengujian dapat disimpulkan bahwa hipotesis satu $\left(\mathrm{H}_{1}\right)$ yang menyatakan bahwa pengungkapan tanggung jawab sosial perusahaan berpengaruh positif terhadap kinerja keuangan diterima. Hasil penelitian ini mendukung penelitian terdahulu yang dilakukan oleh Tsoutsura (2004), Harjoto dan Hoje (2007), serta Almilia dan Wijayanto (2007). Tsoutsura (2004) membuktikan bahwa tanggung jawab sosial perusahaan berpengaruh positif terhadap kinerja keuangan perusahaan. Penelitian Harjoto dan Hoje (2007) dapat membuktikan bahwa pengungkapan tanggung jawab sosial perusahaan berpengaruh positif terhadap kinerja keuangan perusahaan. Almilia dan Wijayanto (2007) menemukan adanya pengaruh positif pengungkapan tanggung jawab sosial perusahaan terhadap kinerja keuangan. Hal ini memberikan penjelasan bahwa pengungkapan tanggung jawab sosial perusahaan memberikan dampak positif pada kinerja keuangan perusahaan yang tercermin pada tingkat return tahunan perusahaan.

Dari hasil pengujian menunjukkan semakin banyak item tanggung jawab sosial perusahaan yang diungkapkan oleh perusahaan maka semakin tinggi kinerja keuangan atau dengan kata lain semakin besar laba yang diperoleh perusahaan. Ditinjau dari teori stakeholders bahwa eksistensi perusahaan ditentukan oleh stakeholdersnya (Devina, et al. 2004). Hal ini mencerminkan bahwa jika perusahaan dapat menjaga hubungan baik dengan masyarakat, pemerintah, investor, para pekerja, dan pihak lain, perusahaan tersebut mendapatkan citra positif dan dukungan dari para stakeholders sehingga pertumbuhan dan keberlangsungan hidup perusahaan akan terjamin.

\section{Pengaruh tanggung jawab sosial perusahaan terhadap kinerja keuangan dengan tata kelola perusahaan sebagai pemoderasi}

Berdasarkan hasil pengujian dapat disimpulkan bahwa hipotesis dua $\left(\mathrm{H}_{2}\right)$ yang menyatakan tata kelola perusahaan memoderasi pengaruh tanggung jawab sosial terhadap kinerja keuangan diterima. Dari hasil uji interaksi, tata kelola perusahaan terbukti sebagai variabel moderasi yang akan memperlemah pengaruh pengungkapan tanggung jawab sosial perusahaan terhadap kinerja keuangan.

Hasil penelitian ini mendukung penelitian terdahulu yang dilakukan Brown and Caylor (2004), Darmawati et al. (2005), dan Setiyowati (2011). Hasil riset Brown and Caylor (2004) menunjukkan tata kelola perusahaan berpengaruh positif terhadap kinerja keuangan. Darmawati et al. (2005) membuktikan bahwa tata kelola perusahaan berpengaruh positif terhadap kinerja perusahaan. Setiyowati (2011) meneliti tentang pengaruh pengungkapan tanggung jawab sosial perusahaan terhadap kinerja keuangan dengan mekanisme tata kelola perusahaan sebagai moderasi. Hasil penelitian ini menemukan bahwa tanggung jawab sosial perusahaan berpengaruh terhadap kinerja keuangan dan mekanisme tata kelola perusahaan sebagai variabel moderasi terbukti memperkuat pengaruh penerapan tanggung jawab sosial perusahaan terhadap kinerja keuangan.

Ditinjau dari teori agensi dengan adanya penerapan tata kelola perusahaan dapat digunakan sebagai bentuk monitoring untuk mengurangi adanya masalah agensi atau tindakan menyimpang yang muncul antara pihak manajemen sebagai pengelola dengan pemilik perusahaan. Pengungkapan tata kelola perusahaan mengisyaratkan bahwa pihak manajemen lebih transparan dalam mengelola perusahaan dan menerapkan prinsip-prinsip tata kelola perusahaan. Jika semakin tinggi interaksi tanggung jawab sosial perusahaan dan tata kelola perusahaan maka akan menurunkan kinerja keuangan. Apabila ditinjau dari teori agency jika priciple telah memberikan kepada agen maka terdapat potensi konflik yang disebut dengan agency problem yang timbul karena adanya perbedaan kepentingan antara agen dan principle. Upaya mengatasi agency problem dibutuhkan agency cost, yang digunakan untuk monitoring perilaku agen. Salah satu bentuk monitoring yang dapat dilakukan yaitu dengan melakukan CSR dan CG. Konsekuensinya perusahaan harus mengeluarkan sejumlah dana untuk pembiayaan 
Pengaruh

Tanggung

Jawab... monitoring, sehinga biaya yang dikeluarkan tersebut akan mengurangi laba perusahaan yang dapat menurunkan kinerja keuangan. Namun apabila ditinjau dari segi legitimasi perusahaan akan mendapatkan citra yang baik dari masyarakat.

\section{SIMPULAN}

Penelitian ini menguji pengaruh tanggung jawab sosial perusahaan terhadap kinerja keuangan dengan tata kelola perusahaan sebagai pemoderasi. Dari hasil penelitian ini dapat disimpulkan, yaitu:

1. Kinerja keuangan akan semakin tinggi apabila perusahaan semakin luas melakukan pengungkapan tanggung jawab sosial. Hal ini membuktikan bahwa kinerja keuangan dipengaruhi oleh pengungkapan tanggung jawab sosial. Hal ini ditunjukkan dengan adanya pengaruh positif antara tanggung jawab sosial perusahaan terhadap kinerja keuangan. Kinerja keuangan perusahaan yang baik diwakili oleh tanggung jawab sosial yang baik karena tanggung jawab sosial juga menunjukan bahwa secara finansial perusahaan tersebut dapat mengatur dan mengelola perusahaannya dengan baik.

2. Kinerja keuangan semakin menurun jika semakin tinggi interaksi pengungkapan tanggung jawab sosial perusahaan dan tata kelola perusahaan. Hal ini disebabkan karena perusaahaan harus mengeluarkan biaya pengawasan atau monitoring cost melalui penerapan tata kelola perusahaan. Belum maksimalnya penerapan tata kelola ini menyebabkan biaya yang dikeluarkan tersebut akan mengurangi laba perusahaan yang justru menurunkan kinerja keuangan.

\section{Impilkasi Penelitian}

Hasil penelitian ini memiliki beberapa implikasi yang dapat digunakan untuk pengembangan teori, implikasi praktik, dan implikasi kebijakan.

\section{Implikasi teoritis}

Hasil penelitian ini memberi implikasi untuk pengembangan ilmu pengetahuan sebagai berikut:

1. Hasil penelitian ini memberikan tambahan kajian teori stakeholders, yaitu memperoleh gambaran yang lebih komprehensif dalam memahami fenomena yang berkaitan dengan pengaruh tanggung jawab sosial perusahaan terhadap kinerja keuangan dengan tata kelola perusahaan sebagai pemoderasi. Temuan ini memberikan implikasi bahwa pengungkapan tanggung jawab sosial di Indonesia masih bersifat ingin memeroleh nilai positif dari stakeholders bukan atas dasar kesadaran perusahaan untuk menjaga lingkungan sekitar, tetapi lebih bersifat ekonomis.

2. Hasil penelitian ini memberikan tambahan kajian teori agensi, yaitu memperoleh gambaran yang lebih komprehensif dalam memahami fenomena yang berkaitan dengan pengaruh tanggung jawab sosial perusahaan terhadap kinerja keuangan dengan tata kelola perusahaan sebagai pemoderasi. Temuan ini memberikan implikasi bahwa perusahaan yang menerapkan tata kelola perusahaan belum dilakukan secara maksimal dan masih bersifat formalitas untuk mematuhi regulasi pemerintah.

\section{Impilkasi Praktis}

Hasil penelitian ini dapat memberi implikasi praktis untuk perusahaan dan investor, antara lain sebagai berikut:

1. Hasil penelitian ini menunjukan bahwa semakin banyak item pengungkapan tanggung jawab sosial perusahaan, maka hal tersebut akan berpengaruh 
terhadap kinerja keuangan sehingga perusahaan akan memeroleh laba yang tinggi dari setiap lembar saham yang dimiliki.

2. Hasil penelitian ini menunjukan bahwa semakin tinggi interaksi tanggung jawab sosial perusahaan dengan tata kelola perusahaan terhadap kinerja keuangan, semakin rendah kinerja keuangan perusahaan. Hal ini dapat memberi bukti tambahan bagi perusahaan jika dalam penerapan tata kelola perusahaan belum dilakukan secara maksimal dapat menurunkan kinerja keuangan karena banyak biaya-biaya yang dikeluarkan untuk menerapkan tata kelola perusahaan tersebut.

\section{Implikasi kebijakan}

Sebaiknya, pemerintah mulai mempertimbangkan untuk menetapkan sanksi yang tegas kepada perusahaan nasional maupun asing tentang kewajiban perusahaan mengenai pengungkapan tanggung jawab sosial dan penerapan tata kelola bagi semua perusahaan.

\section{Keterbatasan}

Keterbatasan dalam penelitian ini adalah sampel penelitian relatif sedikit karena perusahaan yang terdaftar di BEI banyak yang tidak mengikuti Corporate Governance Perception Index (CGPI) yang diselenggarakan oleh IICG. Hal ini disebabkan perusahaan yang akan mengikuti kegiatan ini diwajibkan mengeluarkan sejumlah biaya serta keterbatasan dalam data laporan keuangan perusahaan yang digunakan untuk mendukung penelitian.

\section{Saran}

Adanya keterbatasan-keterbatasan yang ada pada penelitian ini diharapkan akan diatasi oleh peneliti berikutnya dan dapat menjadi acuan perbaikan pada penelitian sejenis di masa yang akan datang. Saran-saran yang dapat disampaikan oleh peneliti, antara lain:

1. Bagi pihak manajemen diharapkan agar lebih lengkap sehingga memenuhi unsur Tanggung jawab (Responsibility), Keterbukaan informasi (Transparancy), Akuntabilitas (Accountability), Kesetaraan dan kewajaran (Fairness) dan Kemandirian (Independency) dalam mengungkapkan semua kegiatan yang berhubungan dengan tata kelola perusahaan dan tanggung jawab sosial perusahaan dalam laporan keuangan.

2. Untuk penelitian selanjutnya, sebaiknya menggunakan proksi tata kelola perusahaan yang berbeda misalnya, menggunakan variabel tata kelola perusahaan yang lain seperti transparansi dan akuntabilitas untuk menemukan nilai tambah dalam perusahaan. Dalam pengukuran kinerja keuangan sebaiknya menggunakan proksi kinerja keuangan yang lain sehingga dapat menemukan pengukuran yang lebih efektif dalam mengukur kinerja keuangan serta menambah jumlah sampel dan menambah jangka waktu pengamatan agar diperoleh kondisi yang sebenarnya.

\section{DAFTAR PUSTAKA}

Akhtaruddin, Mohamed., Monirul Alam Hossain., Mahmud Hossain dan Lee Yao. 2009 Corporate Governance and Voluntary Disclosure in Corporate Annual Report in Malaysian listed Firm. JAMAR. Vol 7 November.

Almilia, Luciana Spica, dan Dwi Wijayanto. 2007. Pengaruh Environtmental Performance dan Environmental Disclosure terhadap Economic Performance. FEUI. The $1^{\text {st }}$ Accounting Conference, 7-9 September 2007. 
Pengaruh

Tanggung

Jawab...
Ambadar, Jackie. 2008. Corporate Social Responsibility (CSR) dalam Praktik di Indonesia. PT. Elex Media Komputindo. Jakarta.

Bathala, C. T., and Moon, K. R., Roa, R, P. 1994. Managerial Ownership, Debt Policy, and the Impact of Institutional Holding, and Agency Perspective, $\mathrm{Fi}^{-}$ nancial Management vol. 23: 38-50.

Brammer, Stephen., Chris Brooks., and Stephen Pavelin. 2005. "Corporate Social performance and Stock Return: UK Evidence from Dissagregate Measures. Financial Management. http://www.ssrn.com. Diakses pada tanggal 24 Februari 2013.

Brown, Lawrence and Marcus L. Caylor. 2004. Corporate Governance and Firm Performance. Working Paper Series. http://ssrn.com. Diakses pada tanggal 24 Februari 2013.

Combes, Paul dan Mark Watson. 2000. Three Survey on Corporate Governance. The McKinsey Quarterly, No. 4.

Darmadji, Tjiptono dan Fakhruddin. 2001. Pasar Modal Di Indonesia: Pendekatan Tanya Jawab. Edisi Pertama. Salemba Empat. Jakarta Darmawati, Deni. 2003. Corporate Governance dan Manajemen Laba: Suatu Studi Empiris. Jurnal Bisnis dan Akuntansi. Vol. 5 No. 1.Hal 46-68.

Darmawati, Deni. 2003. Corporate Governance dan Manajemen Laba: Suatu Studi Empiris. Jurnal Bisnis dan Akuntansi. Vol. 5 No. 1, hal 46-68.

Darmawati, Deni Khomsiyah., dan Rika Gelar Rahayu. 2005. Hubungan Corporate Governance dan Kinerja Perusahaan. Ikatan Akuntan Indonesia. Jurnal Riset Akuntansi Indonesia. Vol. 8, No. 1, Januari 2005. Hal. 65-81.

Deegan, Craig. 2004. Financial Accounting Theory. McGraw-Hill Australia. Pty Limited.

, Craig dan Michaela Rankin, 1996. Do a Australian Companies Report Environtmental News Objectively? An Analysis of Environtmental Disclosures Firms Prosecuted Succesfully by the Environtmental Protection Authority. Accounting, Auditing, and Accountability Journal. Pp 50-68.

Devina. 2004. Pengaruh Karakteristik Perusahaan terhadap Pengungkapan Sosial Perusahaan dalam Laporan Tahunan Perusahaan Go Public di BEJ, Thesis, Magister Akuntansi Universitas Diponegoro. Semarang.

--___ F. F. L. Suryanto dan Zulaikha. 2004. Pengaruh Karakteristik Perusahaan terhadap pengungkapan Sosial dalam Laporan Tahunan Perusahaan Go Public di Bursa Efek Jakarta. Jurnal Manajemen, Akuntansi \& Sistem Informasi 4: 161-177.

Engel, R., M. Hayes,. and X. Wang. 2007. The Sarbanes-Oxley Act and Firm Going Private Decisions. Journal of Accounting and Economic 44(1/2): 116-145.

Eisenberg, T., Sundgren, S., and Wells, M. T. 1998. Larger board size and decreasing firm value in small firms, Journal of Financial Economics, 48: 35-54.

Epstein, Marc J., and Martin Freedman. 1994. Social Disclosure and The Individual Investor. Accounting, Auditing \& Accountability Journal, 7 (4): 94-109.

Fauzi, H., Mahoney L., and Rahman AA. 2007. The Link Between Corporate Social Performance and Financial Performance: Evidence From Indonesian Companies. Issues in Social and Environmental Accounting 1 (1): 149-159.

Finch, Nigel. 2005. The Motivations For Adopting Sustainability Disclosure. MGSM Working Papers In Management. Macquarie University. Australia.

Fiori G., Donato F., and Izzo M F. 2007. Corporate Social Responsibility and Firms Performance, an Analysis Italian Listed Companies. http://www.ssrn.com. Diakses pada tanggal 24 Februari 2013.

Ghozali, Imam. 2006. Aplikasi Analisis Multivariate degan Program SPSS. Cetakan Keempat, Badan Penerbit Universitas Diponegoro, Semarang. 
-.-____ Imam., dan Anis Chariri. 2007. Teori Akuntansi Edisi 3. Semarang: Badan Penerbit Universitas Diponegoro, Semarang.

Gujarati, D. 1997. Basic Econometrics. Forth Edition. New York: Mc.Graw-Hill.

Gunarsih, Tri. 2003. Struktur Kepemilikan Sebagai Salah Satu Mekasnisme Corporate Governance. Jurnal KOMPAK Nomor 8.

Gray, R., Reza K,. dan Simon L. 1996. Corporate Social and Environmental Reporting: A review of Literature and a Longitudinal Studi of UK Disclosure. Accounting, Auditing and Accountability Journal. Vol. 8 (2): 47-77.

, Rob, Muhammad Javad., David M. Power dan C. Donald Sinclair. 2001. Social and Environmental Disclosure and Corporate Characteristics: A Note and Extension. Journal of Business Finance and Accounting pp 327-356.

Gruszczynski, Marek. 2006. Corporate Governance and Financial Performance of Companies in Poland. International Advances in Economic Research, Springer, vol. 12(2), pages 251-259, May.

Hackston, David and Markus, J. Milne. 1996. Some Detrminants of Social and Environtmental Disclosure in New Zealand Companies. Accounting, Auditing, and Accountability Journal. Vol. 9 No. 1 pp. 77-108.

Halim, Abdul. 2007. Manajemen Keuangan Bisnis. Ghalia Bogor. Indonesia.

Hanafi, Mamduh dan Abdul Halim. 2003. Analisis Laporan Keuangan. AMP-YKPN. Yogyakarta.

Haniffa, R.M., dan T.E Cooke. 2005. The Impact of Culture and Governance on Corporate Social Reporting. Journal of Accounting and Public Policy, Elsevier. 391-430.

Harjoto, Maretno A, dan Hoje Jo. 2007. Corporate Governance and Firm Value: The Impact of Corporate Social Responsibility. Graduate School of Business Reasearch Paper No. 1993 Rock Center for Corporate Governance. Working Paper No. 45.

Hartono, Jogiyanto. 2003. Teori Portofolio dan Analisi Investasi. Edisi 2. BPFEUGM Yogyakarta.

-.-___ Jogiyanto. 2006. Metodologi Penelitian Bisnis: Salah Kaprah dan Pengalaman-pengalaman. BPFE-UGM, Yogyakarta.

Horne, Van., and John M. Wachowicz. 2005. Prinsip-Prinsip Manajemen Keuangan. Salemba Empat. Jakarta.

Huafang, Xiao and Jianguo Yuan. 2007. Ownership Strucure, Board Composition and Corporate Voluntary Disclosure: Evidence from Listed Companies in China. Managerial Auditing Journal Vol. 22 No. 6.

Ikatan Akuntansi Indonesia, 2007. Standar Akuntansi Keuangan. Jakarta: Interaksara.

Jensen, M., and W. Meckling. 1976. "Theory of the Firm: Managerial behavior agency cost, and ownership structure". Journal of Finance Economics 3. Pp. 305-360.

Johnson, S., Boone, P., Breach, A., and Friedman, E., 2000. Corporate Governance in the Asian Financial Crisis. Journal of Financial Economics 58, 141$\} 186$.

Klapper, Leora dan Inessa Love. 2002. Corporate Governance, Investor Protection and Performance in Emerging Market World Bank. http://ssrn.com/abstract=303979. Diakses pada tanggal 24 Februari 2013.

Kotler, Philip and Nancy Lee. 2005. Corporate Social Responsibility. Amerika: John Wiley \& Sons, Inc.

Leng, Allan Chang Aik. 2004. The Impact of Corporate Governance Practice on Firm Financial Performance: Evidence from Malaysian Companies. ASEAN Economic Bulletin, 21(3): 308-320.

Mahoney L dan Robert R. 2003. Corporate Social and Environtmental Performance and Their Relation to Financial Performance and Institusional Ownership: 
Pengaruh

Tanggung

Jawab...
Empirical Evidence on Canadians Firms. School of Accounting University of Central Florida. http://www.accounting.rutgers.edu. Diakses pada tanggal 24 Februari 2013.

Munawir. 2002. Analisis Laporan Keuangan, Edisi ketiga belas. Liberti. Yogyakarta.

Miharjo, Setiyono. 2008. Corporate Governance \& Kinerja Perusahaan. Majalah Investor Edisi Mei.

Nwanji, T. I, dan K. E. Howell. 2007. A Review of The Two Main Competing Models of Corporate Governance. The Shareholdership Model Versus the Stakeholders Model. Corporate Ownership and Control Volume 5 (1): 9-23.

Owen, D. 2005). "CSR after Enron: A Role for the Academic Accounting Profession?", European Accounting Review, Vol.14 (2), pp.395-404.

Paul, C. J. Morrison and Siegel, D. S. 2006. Corporate Social Responsibility and Economic Performance. University of California, Davis - Department of Agricultural and Resource Economics and University at Albany, SUNY. Working Paper Series. http://www.ssrn.com. Diakses pada tanggal 24 Februari 2013.

Republik Indonesia. Keputusan Ketua Badan Pengawas Pasar Modal (BAPEPAM) dan Lembaga Keuangan No.Kep-134/BL/2006 tentang Tanggung Jawab Sosial Perusahaan (Corporate Social Responsibility).

. Keputusan Mentri Badan Usaha Milik Negara No. Kep-117/ M-Mbu/2002 tentang Penerapan Praktik Tata Kelola Perusahaan (Corporate Governance) Pada Badan Usaha Milik Negara (BUMN). -..-. Peraturan Badan Pengawas Pasar Modal (BAPEPAM) No. VIII.G.2 Tentang Laporan Keuangan dan Kesesuaian. . Undang-Undang No. 23 Tahun 1997 Pasal 6 Ayat 2 tentang Pengelolaan Lingkungan Hidup.

Undang-Undang No. 25 Tahun 2007 Pasal 15(b) tentang Penanaman Modal.

Undang-Undang No. 40 Tahun 2007 tentang Tanggung Jawab Sosial Perusahaan (Corporate Social Responsibility).

Reverte, C. 2008. Determinants of Corporate Social Responsibility Disclosure Ratings by Spanish Listed Firms. Journal of Business Ethics 88: 351-366. http:// springer.com. Diakses pada tanggal 28 Februari 2013.

Said, Roshima, Yuserrie Hj. Zainuddin, dan Hasnah Haron. 2009. The Relationship between Corporate Social Responsibility and Corporate Governance Characteristic in Malaysian Public Listed Companies. Social Responsibility Journal. Vol. 5, No. 2, hal 212-226.

Saidi, Zaim dan Hamid Abidin. 2003. Sumbangan Sosial Perusahaan, Cetakan Pertama. Piramedia. Jakarta.

Santoso, Singgih. 2012. Aplikasi SPSS pada Statistik Parametrik. PT. Elex Media Komputindo. Jakarta.

Sekaran, Uma. 2006. Metodologi Penelitian Untuk Bisnis, Edisi. Salemba Empat. Jakarta.

Sembiring, Eddy Rismanda. 2003. Karakteristik Perusahaan dan Pengungkapan Tanggung Jawab Sosial: Study Empiris pada Perusahaan yang tercatat di Bursa Efek Jakarta. Thesis, Program Pascasarjana Universitas Diponegoro. Semarang.

Setiyowati, Supami Wahyu. 2011. Pengaruh Pengungkapan Corporate Social Responsibility terhadap Kinerja Finansial Perusahaan dengan Corporate Governance sebagai Pemoderasi, Thesis, Program Magister Akuntansi, Program Pascasarjana Fakultas Ekonomi Universitas Brawijaya. Malang.

Singarimbun dan Effendi. 1995. Metode Penelitian Survei. LP3ES. Jakarta.

Sugiyono. 2010. Metode Penelitian Kuantitatif Kualitatif dan R\&D. Bandung: Alfabeta. 
Suharto, Edi. 2008. Menggagas Standar Audit Program CSR. Bandung.

Suratno, Ignatius Bondan., Darsono., dan Siti Mutmainah. 2007. Pengaruh Environtmental Performance terhadap Environmental Disclosure dan Economic Performance. The Indonesian Journal of Accounting Research Vol 10 No. 2 Tahun 2007.

Suwardjono. 2005. Teori Akuntansi Perekayasaan Pelaporan Keuangan. Yogyakarta: BPFE.

Syakhroza, Akhmad. 2003. Best Practices Corporate Governance: dalam Konteks Kondisi Lokal Perbankan Indonesia. Usahawan No. 06 Th XXXII, Juni 2003.

Tampubolon, Manahan. 2005. Manajemen Keuangan (Finance Management), Cetakan Pertama. Penerbit Ghalia Indonesia. Bogor.

Titisari, Kartika Hendra., Eko Suwardi., dan Dody Setiawan. 2009. Corporate Social Responsibility (CSR) dan Kinerja Perusahaan. Dinamika Manajemen, Vol. 1, No. 1, November. Fakultas Ekonomi Universitas Islam Batik. Surakarta.

Trisnanigsih, S. 2007. Independensi Auditor dan Komitmen Organisasi sebagai Mediasi Pengaruh Pemahaman Good Corporate Governance, Gaya kepemimpinan, dan Budaya. Universitas Pembangunan Nasional (UPN) "Veteran". Jawa Timur.

Tsoutsura, Margarita. 2004. Corporate Social Responsibility and Financial Performance. School of Business Berkeley, California. http:// responsiblebusiness.haas.berkeley.edu. Diakses pada tanggal 20 Februari 2013.

Utama, Sidharta. 2008. Evaluasi Infrastruktur Pendukung Pelaporan Tanggung Jawab Sosial dan Lingkungan di Indonesia. http://www.ui.ac.id/id/news/ archive/410. Diakses pada tanggal 28 Februari 2013.

Wibisono, Yusuf. 2007. Membedah Konsep dan Aplikasi Corporate Social Responsibility, Fascho Publishing: Jawa Timur.

Widioatmojo, Sawidji. 2004. Cara Cepat Memulai Investasi Saham: Panduan Bagi Pemula, cetakan Pertama. PT. Elex Media Komputindo. Jakarta.

Zarkasyi, Mohammad Wahyudin. 2008. Good Corporate Governance: pada Badan Usaha Manufaktur, Perbankan, dan Jasa Keuangan Lainnya. Alfabeta. Bandung. 
